УДК: 7.034(450)

ББК: 85.14

A43

DOI:10.18688/aa166-5-40

Laura De Zuani

\title{
A Controversial Painting by Bartolomeo Montagna: A New Hypothesis for a Notable Piece in the Early Production of the Head Painter of Vicenza
}

Bartolomeo Montagna was born in Orzinuovi, a small town near Brescia, in northern Italy, but lived and worked in Vicenza ${ }^{1}$. He was born around 1452, when Giovanni Bellini was the leader of the Venetian painting renovation [27]. Information on his early production can only be deduced from a substantial number of documents which present him as an artist deeply involved in the artistic life of Vicenza. He was probably trained by an obscure painter called Gianfrancesco Somaio, whose name appears in archival documents next to Montagna's ${ }^{2}$. The first record of this kind is, in fact, dated 1476 [21]. Since none of Gianfrancesco's or Bartolomeo's early paintings survived, we can only imagine this early production, which must have been influenced by Antonello da Messina's heritage, but with simpler definition of volumes and crystalline light of the Sicilian master. On the basis of two other documents, we were also able to state that Montagna visited Venice twice, between 1469 and 1482: in the first document the painter is said to be living in civitate venetiarum (i. e. in the Lagoon), and for this reason he was not able to witness an estate sale in Vicenza ${ }^{3}$. In the second one, the most interesting for us, he is involved in the decoration of the Scuola Grande di San Marco, as a substitute of the busier Giovanni Bellini ${ }^{4}$. We must remember that also Giovanni Bellini was working in Vicenza around 1480 in the Fioccardo chapel inside the Cathedral. The innovative elements of Bellini's painting made a huge impression on all local artists and the prestigious role accorded to the Fioccardo family inspired also other noble families of Vicenza.

The importance of this Venetian component for the young Montagna clearly emerges if we compare Bellini's Resurrection (now in Berlin) to one of his early drawings, now in the Albertina Collection in Wien (inv. n. 24437). This drawing (brown ink on white paper, with brush) shows Noah's drunkenness and may have been part of the first project for the decoration of the San Marco Scuola. The general asset of the composition is a specular version of the one we see in the Berlin painting and clearly testifies the relationship with Bellini. The essentially quattrocentesque nature of the composition is also defined by the heavy contour line; the handling is uncertain and the dependence on Bellini is evident even in Noah's hair locks [15].

My gratitude to Sarah Ferrari and Dott. Matteo Massaro, for their precious consultation.

2 Archivio di Stato di Vicenza, Notarile, Gregorio del fu Giacomo da Malo, b. 4643 (libretti) 29 ottobre 1476.

Archivio di Stato di Vicenza, Notarile, Daniele Ferretto, b. 4618, cc. 23v-32r.

Archivio di Stato di Venezia, Scuola Grande di San Marco, Notatorio 1482-1503, b. 16 bis. 
In order to gain a better understanding of Bartolomeo's cultural references in the early 1480 s we should step back to a document that testifies the existence of an altar dedicated to the Virgin, Saint Lucy and Saint Nicholas in the Servites church of Vicenza: "Bartholomeus Baldanucius civis vicentinus divo nicolao testamento ponendum iussit Joannes Magrades executor prius, Laurentii inde ejus filii heres, suo etiam et suorum nomine faciendum locavit" [7, p. 100]. The dedication of this altar, ordered by the noble man Bartolomeo Baldinucci and executed by Giovanni Magrè, is now proved by a later document, unknown until now, which remembers the daily mass celebrated in honor of the same Baldinucci: "313 Ad altare S. Nicolai quotidie una missa pro anima D. Bartholomei Baldanuciis et eius defuntorum" "The Sacra Conversazione has a simplified structure, the harsh landscape reminds of Giovanni Bellini, while Nicholas resembles Saint Cassian in Antonello da Messina's masterpiece, and the soft features of Saint Lucy bring back to the heritage of the Venetian school derived from Alvise Vivarini. The space conception is undeveloped, due to the uncertain perspective showed by the floor lines, turning the whole composition on the foreground. The dark range of colours finally connects this painting to a small fresco fragment coming from the church of Magrè, a small town near Vicenza, which an old inscription dates to 1481. The oval and gentle face of Saint Lucy resembles Vivarini's models, as well as a small Virgin and Child now in Castelvecchio museum (Verona), almost unanimously recognized as an early work [8].

Some years later Bartolomeo Montagna produced another painting, whose consideration among scholars is less linear. It was seen by the $17^{\text {th }}$ century chronicler Boschini in the Vicentine church of Saints Clare and Bernard, but wrongly referred to the minor painter Giovanni Speranza [9, p. 95]. Since then, this painting has always been confused by historians with another one, seen by Boschini in Saint Blaise church and attributed to Benedetto Montagna, son of Bartolomeo. I am now able to rewrite the history of this Madonna and Child with Saint Francis and Saint Bernard, and to confirm its provenance from the Franciscan church. This altarpiece had been chosen by the ministers Fumagalli and Appiani to enter the Royal Collections of Brera, after Napoleonic suppressions, as a quadro di pregio (that means a valuable painting), representative of Italian culture. It is recorded in the Brera collections, where it is still housed by Fumagalli's documents since 15 January $1812^{6}$. I believe this date should be considered as the first proof of the provenance of this altarpiece from the church of Saint Clare, which was suppressed by Napoleonic laws in 1810. Saint Blaise was, in fact, abolished in 1797, which means almost fifteen years before the painting entered the Royal Collections.

I must recall an old inscription, seen once again by Boschini on the right chapel wall of the Church of Saint Clare which identified a tomb owned by the Valmarana family: "NICOLAUS, ET ANTONIUS Q. FRANCISCI, STEPHANUS, GEORGIUS ET ALEXANDER Q. BENEDICTI DE VALMARANIS S. POSTERISQ. S. M. H. V. P.” Nicolò Valmarana actually dictated his will on May, 24 1484. He "legavit et fieri iussit anconam unam in ecclesie S. bernardini burgi Berice ad altare unum dicte ecclesie cum imaginibus b. Virginis Marie, S. Francisci et

\footnotetext{
5 Archivio di Stato di Vicenza, Corporazioni Religiose Soppresse, Santa Maria dei Servi, Serviti di Vicenza, c. 9 r.

$6 \quad$ Archivio di Stato di Milano, Studi P. M., b. 351, fasc. a. Specifica dei quadri provenienti da Chiese e Corporazioni soppresse nel dipartimento del Bacchiglione scelti dai Delegati per le R. R. Gallerie e da spedirsi a Milano, Vicenza, 1811, 3 agosto.
} 
S. Bernardini cum antipecto dicti altaris"'. While the structure of perspective is uncertain, the long and thin figures of the saints resemble the ones Alvise Vivarini painted for the church of Saint Francis in Treviso: a Sacra Conversazione, in which the space is confined to the foreground by a curtain. The same feature appears in Montagna's painting, as well as the same paratactic language.

We can understand the distance between this early production and the more mature works thanks to one painting in particular, ordered for the high altar of the church of Saint Bartholomew in Vicenza. Thanks to Silvestro Castellini's record, we know that the high altar was commissioned by the Trento family, whose coat of arms was set into the wall of the major chapel ${ }^{8}$. In the 1940s, the Vicentine historian Antonio Fasolo stated that this painting was executed in 1484, without any documentary evidence [10, pp. 55-61]. Since then, this masterpiece was settled in the middle of the 1480s, in first instance for its resemblance with Girolamo da Treviso's pala del Fiore, dated 1487. The less talented painter from Treviso must have seen the pala Trento, keeping in mind the illusionistic effect of its high vault. In the pala Trento masterpiece, in fact, Montagna created an illusionistic space, structured by the geometrical lines of the pavement and by the coffered vault, open on the landscape. However, both paintings must be referred first to Giovanni Bellini's Sacra Conversazione, once located in the Venetian Church of Saint John and Paul, known by Francesco Zanotto's engraving [19, pp. 599621]. The relationship with the altarpiece of Saint Cassian, painted around 1475 by Antonello da Messina, also seems to complicate the dating and the comprehension of Montagna's work. The space created by the vault, so similar in Montagna, squeezes Bellini's figures on the first plan instead of placing them in the airy space created by the Vicentine. On the other hand, the Saint Cassian example, proposed once again by the most talented of Montagna's pupils, Giovanni Buonconsiglio, doesn't seem to be an adequate basis for comparison.

The tomb of Antonio Trento, Vicentine jurist who had died in 1467, and his wife Tomasina was located at the centre of the chapel, along with this epitaph: "ANTONIO TRIDENTINO CIVILIS PONTIFICIIQ IURIS CONSULTO ET THOMASINAE PARENTIBUS FILII PIENTISSIMI SIBI AC POSTERIS POSUERE". On May, 141478 the friars of Saint Bartholomew agreed with Giacomo, Francesco and Sebastiano Trento, sons of Antonio, for their father's chapel to be made: "à loro spese con spese di D.ti 200, acciocchè in detta Capella fosse fatta la sepoltura di d. Antonio Loro padre, e poi i loro corpi e de loro heredi e successori..." [30].

Why did the Vicentine nobility want to be buried in that sumptuous but marginal Church? Saint Bartholomew was in fact located in a peripheric position, near to Vicenza's walls and far from the city centre. All nobles and high feudal families, such as the Trissino or the Porto, had their chapels in antique mendicant churches: Santa Corona and San Lorenzo. In Quattrocento, noble families tried to regulate the authority of the Council of Elders, represented by feudal families, diminishing their power inside the Great Council, while in the same time making it more difficult to become a citizen of Vicenza [34, pp. 167-184]. Citizenship was, in fact, the only way to join public and political life in Vicenza. All the families that owned an altarpiece in Saint Bartholomew were obviously part of the Great Council [3, pp. 45-65]. 
In Saint Bartholomew, under construction since 1467, foreign labors worked in different times, for example, stone cutters from Lombardy, such as "Johanne muratore q. Massilii de Bergamo habitante et commorante in dicto monastero or Laurenzio marangono quondam Petri de Pexino Brixiensis disctrictus"'. In December 1487 and April 1488, the famous inlayer Pierantonio degli Abati, called in documents magister perspectivae, and the architect Lorenzo da Bologna [18], protagonist of the Vicentine architectonic Renaissance, were also recorded ${ }^{10}$. So, when Montagna started working in this temple, he must have faced an exciting cultural mix. Saint Bartholomew's church was destroyed in the $19^{\text {th }}$ century, but we can fortunately have a partial idea of its interior disposition thanks to the watercolour that Bongiovanni took some days before ${ }^{11}$. We can verify that the Trento altarpiece was projected to create a dialogue with the central apse structure, making a vertiginous sense of elevation. Montagna used the height of the cross vault and the connection between the frame and the painted space, which is measured by two tension rods, to establish a dialogue between the painted space and the real space of the chapel, for which the panel was intended. The comparison between Saint Clare (1484) and the Trento altarpiece, in fact, will clarify the substantial change of Montagna's language.

We are finally able to set this masterpiece precisely in the year 1485, on the basis of a recently discovered document that records its commission in 1484 with the promise of delivering it within one year [21, pp. 121-122]. The language of the painter, thanks to the familiarity with architectonic and sculptural techniques, evolved in a new conception of perspective, somehow far from Venetian teaching. Once we have specified each phase of Montagna's early production, we can state that the painter seems to travel in a linear and progressive way, from a Venetian and uncertain style to a more complex structure of perspective.

However, in 1487, he signed and dated a small and precious panel, now in the Accademia Carrara in Bergamo, Virgin and Child with Saint Sebastian and Saint Roch. The commission of this panel is recorded by an inscription on the verso, "Mr Bartholomeus Montagna brixianus habitator Vincentiae: hanc depinxit mr Hieronimo roberto brixiano civi et habitatori ibidem, de mense septembris 1487 pro pretio librae 13 cum dimidia planetarum". This inscription, which deceived many historians, says that Bartolomeo Montagna, called master, painted it for Girolamo Roberti in September 1487 and received the payment of 13 lire pianete and half. Bartolomeo Montagna is also called brixianus, i. e. from Brescia, such as the commissioner Girolamo Roberti. Our painter was actually born in Orzinuovi, near Brescia, but he had never been called bresciano in official documents, probably because he moved to Vicenza when he was just a child in 1459. So his patron must have known Bartolomeo Montagna's original provenance and presumably liked it for its resemblance with his own.

This small and squared panel measures $60 \mathrm{~cm}$ for every side. It presents The Virgin and Child with Saint Roch and Saint Sebastian; on the background there is a rocky landscape and some kind of watercourse, maybe a lake. The excellent conservation and the recent restoration allow a clear reading of the painted surface, making us able to appreciate the preciousness of the painterly matter and the elegance of the details. The figures stand on the decorated floor, 
which is defined and squared by the geometrical drawing of different coloured marbles, reflected in the multicolor parapet behind the Virgin and in the rusty orange porphiry of the throne. The Virgin casts her shadow on a curtain which divides the Sacra Conversazione from the background, following a quattrocentesque scheme preferred by the young Montagna. The landscape, for its part, reflects the Venetian teaching and leaves to paths and small trees the task to follow our sight between different planes of composition. In this small panel the structure of perspective is widely neglected, it seems to be sacrificed to the advantage of decorative elements, fine strokes of the brush and attention to details. It shares the perspicuity of the landscape and the general antonellesque feeling with the Philadelphia painting which must be placed, as already said, at the beginning of the 1480s. The architectonical elements are absent except for Saint Sebastian's column which represents a further pretext for decorativism. In the lower middle a probably authentic signature is overpainted with a later and not authentic one.

Some historians, Lionello Puppi first [27], doubted the date, thinking it might be referred to the handover moment, while the painting must have been stored for many years in Montagna's workshop. Following this assumption, Montagna must have been keeping this panel from the early 1480s until September 1487, and then he delivered it to a quite hard to please commissioner. I must confess now my difficulties in accepting such a late date for the Bergamo painting, as well as to suppose its storage in Montagna's workshop, waiting for someone to buy. It must have been made for that specific commissioner in a precise moment. The small format, the underlined Brescian origin of the painter in the verso inscription, the price recorded in Brescian currency and finally the presence of Saints Sebastian and Roch lead us to another hypothesis. These two Saints, as well known, are usually invoked during pestilences. In 1465-1467, in Brescia, a typhoid fever, preceded by locust infestation, killed a large part of the population. Later in 1478 , when people both in the city and the country had already been decimated by plagues which occurred in 1468-1469 and 1473-1474, a stronger pestilence took place [31, pp. 175-179]. Jacopo Melga, a Brescian chronicler, called it "mal de zucheto", because the fever appeared first with a terrible headache [16, pp 10-29]. The plague was very contagious and there was no way to prevent the spread of this disease. People started escaping from the city, since the people infected were first brought to the hospital of San Bartholomew, and then left on the streets of the almost deserted city. The provvisioni of the City Council record a lot of important notices about health care. It was even forbidden to enter the city for people coming from Venice, which was considered the original place of the disease. A decrease in deaths occurred from the autumn of 1478 until the spring of 1479, when Brescians thanked Saint Roch with a big procession and started building a brand new church for the miracle worker Saint. Roch was a recently canonized Saint, so he was usually venerated with the more traditional thaumaturge Sebastian, whose arrow wounds resembled the plagues caused by the illness.

The hagiographical tradition started in 1430, when an anonymous author wrote a Vita of Saint Roch, and went on with the well-known biography written in 1475 by Francesco Diedo, a Venetian jurist and humanist [12]. Traditional iconography presents Roch as a young, bearded man, dressed as a pilgrim with a wide-brim hat, the shell and a black belt. From his loosened stockings he shows the first wound of plague, which usually appears in the groin. Roch came from the Languedoc in the second half of the $14^{\text {th }}$ century and died of consump- 
tion in a prison in Voghera, accused of being a spy. He contracted plague in Italy and decided to isolate himself as a hermit, waiting for his death. But instead he was healed, thanks to a dog that every day stole some bread from its rich owner and fed him. Saint Roch appeared with more frequency in the last quarter of the Quattrocento, due to the increase of plague, but the dog attribute appears in the Saint's iconography starting from the late Quattrocento [28].

A strong and famous pestilence took place in Venice in 1478-1479, but the disease soon spread in Brescia (1468) and popular devotion to Saint Roch sometimes forerun official devotional forms [32, pp. 371-378]. The Saint's body was found on February, 281469 in Voghera, at the same time when Roch appeared in fresco cycles in Brescia. Worship testimonies were carried out later in Vicenza, following the great and terrible plague outbreak in 1485 [12]. In the same year the City Council, looking for a divine intermediary to decrease the pestilence, decided to build a temple in honor of Saint Roch. Considering that this little panel offers evident signs of contact with the Brescian more than the Vicentine world, and being now persuaded of its relationship with pestilence, we should take into account its possible Brescian origin and then try to find a suitable place for it into Montagna's young production. Accepting the date 1487 finally means agreeing with a substantial contemporaneity of Saint Roch's small panel with the Trento altarpiece, which is an evident link to the production of the 1490s. The development of plague in Brescia in 1478, then in Orzinuovi in 1481, and the consequent beginning of popular devotion should address us towards the end of the 1470s or the beginning of the 1480s. This should be also clear by the comparison with the thin figures in Montagna's painting and Giovanni Bellini's or Antonello da Messina's figures in a few paintings surely located in the 1470s. A strong resemblance also bounds the Bergamo panel to the small fresco fragment, dated 1481, now in the National Gallery of London. The small foot of the baby, with one finger apart from the others, the right hand of the Virgin with tapering fingers and dislocated little fingers and the white veil framing her sweet oval face find better comparisons with this kind of compositions, pertaining the first years of the ninth decade.

So the verso inscription, unless we suppose a mistake by a later copyist, should be read as a commemorative transcription, affixed in a second moment, some years after the actual making of the painting.

Title. A Controversial Painting by Bartolomeo Montagna: A New Hypothesis for a Notable Piece in the Early Production of the Head Painter of Vicenza.

Author. Laura de Zuani, - Ph. D., postdoctoral research fellow. University of Padua, Piazza Capitaniato 7, 35139 Padova, Italy. dezuanilaura@gmail.com

Abstract: The essay presents the painter Bartolomeo Montagna (1452-1523), founder of the Renaissance Vicentine school of painting. The paper starts from his early production side by side with Gianfrancesco Somaio, to the direct comparison with Venetian innovation carried on by Giovanni Bellini. Bartolomeo Montagna got acquainted with the Venetian master during his two journeys to Venice between 1469 and 1483. Looking at his 1480s production, bounded to the Venetian experience and to Antonello da Messina's heritage, the report examines the complex connections between Bartolomeo Montagna, the inlayer Pierantonio degli Abati and the architect Lorenzo da Bologna. The collaboration between these three artists started with the great construction of the Vicentine Church of Saint Bartholomew, and then it went on thanks to the most important artistic workshop in Padua at the end of the $15^{\text {th }}$ century. The first years of the painter's career were examined through archival documents and stylistic analysis in order to confirm a new hypothesis on his patrons. After explaining the complex cultural contributions matched by the painter, we move on to the particular case: a signed and dated painting (1487) which obviously does not correspond to this date. The 
paper offers a new hypothesis regarding the subject of the painting The Virgin and Child with Saint Sebastian and Saint Roch, its date and the unusual position of the inscription (on the reverse side) searching for a more suitable place for this painting in Montagna's artistic career. A new document, regarding Montagna's masterpiece in Saint Bartholomew, recently brought to light by an Italian archivist Manuela Barausse, is also helpful in this case. The essay finally shows how an apparently well-defined case leads to a long journey, in order to comprehend the meaning of the artistic creation.

Keywords: Bartolomeo Montagna; Vicenza; Venetian art; Saint Roch; Lorenzo da Bologna; pestilence.

Название статьи. Новая гипотеза об одной из ранних работ Бартоломео Монтанья, главы школы Виченцы.

Сведения об авторе. Де Зуани Лаура - Ph. D., исследователь. Падуанский университет, площадь Капитаниато, 7, Падуя, Италия, 35139. dezuanilaura@gmail.com

Аннотация. Статья посвящена художнику Бартоломео Монтанье (ок. 1452-1523), основателю ренессансной школы живописи Виченцы. Его ранние произведения рассмотрены в сравнении с работами Джанфранческо Сомайо и такого новатора, как Джованни Беллини. С последним Монтанья контактировал во время двух поездок в Венецию между 1469 и 1483 гг. В связи с работами 1480-х гг., свидетельствующими об освоении художником венецианского опыта и наследия Антонелло да Мессины, исследуется сложная история творческого содружества Бартоломео Монтаньи, мастера инкрустации Пьерантонио дельи Абати и архитектора Лоренцо да Болоньи. Сотрудничество между тремя мастерами началось во время строительства церкви Сан Бартоломео в Виченце. В конце столетия оно получило развитие благодаря важнейшим художественным мастерским Падуи. Для изучения первых лет творчества Бартоломео Монтаньи привлечены архивные материалы и использован метод стилистического анализа, что позволило сделать некоторые новые предположения о его заказчиках.

Характеристика непростой историко-культурной ситуации, в которой работал мастер, предваряет анализ одной картины Монтаньи. Это его подписное произведение, которое датируют 1487 г. Однако, по нашему мнению, оно не могло быть исполнено в это время. В статье высказана новая гипотеза по поводу сюжета картины (Мадонна с Младенцем, св. Себастьяном и св. Рохом), даты ее создания и необычного расположения подписи (на обороте картины). Предпринята попытка определить истинное место этого произведения в творчестве Монтаньи, чему немало поспособствовал недавно обнаруженный итальянской исследовательницей Мануэлой Барауссе архивный документ о шедевре Монтаньи в церкви Сан Бартоломео. Таким образом, статья демонстрирует, как произведение, казалось бы, имевшее точную датировку, может дать повод для большого исследования, позволяющего лучше понять многие аспекты творчества художника.

Ключевые слова: Бартоломео Монтанья; Виченца; венецианские художники; св. Рох; Лоренцо да Болонья; чума.

\section{References}

1. Avagnina M. T. (ed.) Pinacoteca civica di Vicenza, Dipinti dal 14. Al 16. Secolo. Cinisello Balsamo (Mi), Silvana Publ., 2003. 638 p. (in Italian).

2. Barbieri F. Pittori di Vicenza: 1480-1520; Bartolomeo e Benedetto Montagna, Giovanni Buonconsiglio, Giovanni Speranza, Francesco Verla, Marcello Fogolino, Girolamo di Stefano, Giacomo da Vicenza, Girolamo Dal Toso. Vicenza, Neri Pozza Publ., 1982. 78 p. (in Italian).

3. Barbieri F.; Preto P. Storia di Vicenza. Letà della repubblica veneta (1404-1797). Vicenza, Neri Pozza Publ., 1989. 417 p. (in Italian).

4. Bologna F. Antonello da Messina: Catalogue. Milano, Electa Publ., 2013. 169 p. (in Italian).

5. Borenius T. I pittori di Vicenza 1480-1550. Vicenza, Rumor Publ., 1912. 245 p. (in Italian).

6. Carroll E. Bartolomeo Montagna (1459-1523): Civic and Artist Identity in Early Sixteenth-Century Vicenza. Bloomington, Indiana University Publ., 2006. 408 p.

7. Castellini S. Descrizione della città di Vicenza dentro dalle mura. Vicenza, Tip. Staider Publ., 1885. 129 p. (in Italian).

8. Dani A. Opere d'arte di Magrè. Vicenza, 1963. 8 p. (in Italian).

9. De Boer W. H. Marco Boschini. I gioieli pittoreschi : virtuoso ornamento della città di Vicenza; cioè l'endice di tutte le pitture pubbliche della stessa città; Venetia MDCLXXVI. Firenze, Centro Di Publ., 2008. 503 p. (in Italian). 
10. Fasolo G. Guida del Museo Civico di Vicenza. Vicenza, Tip. Commerciale Publ., 1940. 194 p. (in Italian).

11. Fochesato R. (ed.) Santa Chiara in Vicenza: complesso monumentale e istituto palazzolo: storia e restauro. Vicenza, Aeditecne Publ., 2002. 288 p. (in Italian).

12. Forzatti Golia G. Un pellegrino nella terra di Voghera. San Rocco di Montpellier. Selci-Lama (Pg), Editrice Pliniana Publ., 2011. 126 p. (in Italian).

13. Galassi M. C. Il disegno svelato. Progetto e immagine nella pittura del primo Rinascimento. Nuoro, Ilisso Publ., 1998. 150 p. (in Italian).

14. Galassi M. C. Indagini sul disegno sottostante di Bartolomeo Montagna: precisazioni sulla prima attività. Arte Veneta, 2001, 55, pp. 103-112 (in Italian).

15. Gilbert C. Puppi Lionello: Bartolomeo Montagna. The Art Bulletin, 1967, 49, pp. 184-189.

16. Guerrini P. Le cronache bresciane inedite dei secoli XV-XIX trascritte e annotate da Paolo Guerrini, vol. 1. Brescia, Brixia Sacra Publ., 1922. 409 p. (in Italian).

17. Le Goff J. Per una storia delle malattie. Bari, Dedalo Publ., 1996. 407 p. (in Italian).

18. Lorenzoni G. Lorenzo da Bologna. Venezia, Neri Pozza Publ., 1963. 129 p. (in Italian).

19. Lucco M. (ed.) La pittura nel Veneto, Il Quattrocento, vol. 2. Milano, Electa Publ., 1990. 784 p. (in Italian).

20. Lucco M. Antonello da Messina. Lopera completa: Catalogue. Cinisello Balsamo (Mi), Electa Publ., 2006. 383 p. (in Italian).

21. Lucco M. Bartolomeo Cincani detto Montagna: dipinti. Treviso, Zel Publ., 2014. 471 p. (in Italian).

22. Mantese G. Memorie storiche della chiesa vicentina, vol. III/2 (dal 1404 al 1563). Vicenza, Neri Pozza Publ., 1964. 1128 p. (in Italian).

23. Nielsen K. U. Bartolomeo Montagna und die venezianische Malerei des späten Quattrocento. Munich, München University (Diss.), 1995. 276 p. (in German).

24. Ottino Della Chiesa A. La Galleria dell'Accademia Carrara in Bergamo: con l'elenco delle opere. Milano, Alfieri \& Lacroix Publ., 1964. 84 p. (in Italian).

25. Prodi P.; Johanek P. (eds.) Strutture ecclesiastiche in Italia e in Germania prima della Riforma. Bologna, Il Mulino Publ., 1984, pp. 312-351 (in Italian).

26. Pugliese O. (ed.) Venezia e la peste 1348-1797: Catalogue. Venezia, Marsilio Publ., 1980. 380 p. (in Italian).

27. Puppi L. Bartolomeo Montagna. Vicenza, Pozza Publ., 1962. 188 p. (in Italian).

28. Rigon A.; Vauchez A. (eds.) S. Rocco. Genesi e prima espansione di un culto: Acts. Bruxelles, Société des Bollandistes Publ., 2006. 324 p. (in Italian and English).

29. Rossi M. (ed.), La pittura e la miniatura del Quattrocento a Brescia: Acts. Peschiera Borromeo (Mi), Vita e Pensiero Publ., 2001. 165 p. (in Italian).

30. Tomasini F. Theatro genealogico delle famiglie nobili di Vicenza. Venezia, 1677 - Bologna, Forni Editore Publ., 1976. 95 p. (in Italian).

31. Treccani G. Storia di brescia. Vol. 2: La dominazione veneta (1426-1575). Brescia, Treccani Publ., 1963. 1123 p. (in Italian).

32. Turchini A. (ed.) Lo straordinario e il quotidiano. Ex voto, santuario, religione popolare nel bresciano. Brescia, Grafo Edizioni Publ., 1980. 441 p. (in Italian).

33. Valagussa G. (ed.) I grandi veneti da Pisanello a Tiziano, da Tintoretto a Tiepolo. Capolavori dell'Accademia Carrara di Bergamo. Cinisello Balsamo (Mi), Electa Publ., 2010, pp. 61-62 (in Italian).

34. Ventura A. Nobiltà e popolo nella società veneta del ' 400 e '500. Bari, Laterza Publ., 1964. 490 p. (in Italian).

35. Von Hadeln D. (ed.) Carlo Ridolfi. Le Maraviglie dell'Arte, overo le Vite de gl'illustri pittori veneti e dello stato. Roma, Soc. Multigrafica Ed. SOMU Publ., 1965. 442 p. (in Italian). 